\title{
OS HOMENS NÃO AMAM AS MULHERES, DE LUCILENE MACHADO
}

\author{
MACHADO, Lucilene. Os homens não \\ amam as mulheres. São Paulo: Giostri, 2017.
}

Betania Vasconcelos da Cruz Fraga* Altamir Botoso ${ }^{* *}$

A obra Os homens não amam as mulheres foi escrita por Lucilene Machado, que é professora titular na UFMS, cronista e escritora. Ela nasceu no dia 09 de abril, na cidade de Campo Grande, Mato Grosso do Sul. É mestra em Literatura e doutora em Teoria da Literatura pela UNESP. Também atua como pesquisadora da Literatura Sul-Mato-Grossense no Instituto Histórico Geográfico-MS.

Foi bolsista da Agencia Española de Cooperación Internacional-AECI, pela Universidade Complutense de Madrid. É membro da Academia Sul-Mato-Grossense de Letras e da Federação de Academias de Mato Grosso do Sul. Foi cronista por seis anos no Jornal Correio do Estado, de Mato Grosso do Sul. Tem textos publicados na Espanha, Itália, Venezuela e Portugal.

\footnotetext{
* Mestre em Letras (área de Linguagem: Língua e Literatura) pela Universidade Estadual de Mato Grosso do Sul (Uems), campus de Campo Grande-MS.

** Doutor em Letras (área de Teoria Literária e Literatura Comparada) pela UNESP, campus de Assis-SP- Professor de Língua Espanhola da Universidade Estadual de Mato Grosso do Sul (Uems).
} 
A própria escritora se define nos seguintes termos: "Mãe do Lucas e do Kaíque, dona de casa, tia, professora de literatura, doutoranda, espontânea, forte, frágil... Eu seria igual a todas, não fosse essa angústia vertical escorrendo por minhas veias e artérias, a mesma angústia que me leva a escrever". E em sua escrita, se pode perceber a qualidade e o valor estético de uma voz sul mato-grossense que merece ter seus textos lidos e estudados nos meios universitários ou apreciados pelos leitores que gostam de boas histórias.

Os homens não amam as mulheres é uma obra composta 26 crônicas com uma linguagem poética e cheia de desejos, de sensibilidade e paixão exposta à flor da pele. Lucilene Machado faz uma reflexão das mais diversas questões, como o amor e também as questões sociais e culturais do mundo contemporâneo. O leitor vai debruçar-se em uma leitura intimista num estilo que oscila entre o formal e o informal, situada na fronteira entre reflexão e narração literária.

As 26 crônicas são narradas em primeira pessoa, desencadeando um diálogo entre a autora e o leitor. No momento caótico que se encontra o país, Machado busca a grandeza dos pequenos gestos para falar do amor. Vivemos em um período de mudanças profundas no campo político, econômico, social e cultural e a autora tem uma visão contemporânea do ser humano trazendo uma linguagem clara e inteligente dos fatos e dos acontecimentos.

Na primeira crônica, a qual dá nome ao livro, a autora faz uma paródia desconstruindo o que foi dito pelo escritor português Antônio Lobo Antunes, deixando claro que ficou triste ao ler a crônica de Antunes, que diz que "os homens não amam as mulheres", amam sim a condição que as mulheres podem lhes proporcionar. Segundo Antunes, as mulheres dão muito trabalho. Sendo assim, Machado dá uma resposta a isso, dizendo que as mulheres são muito fáceis de agradar, se os homens tivessem vontade e coragem para decifrar seus mistérios e enigmas. Ao logo de sua crônica Machado, vai desconstruindo a ideia de Antunes a respeito das mulheres.

Já na "Crônica às minorias em tempo de massacre", Machado crítica o silêncio da sociedade que se cala diante das atrocidades cometidas em nome da religião, de um deus cruel e desumano. Ela fala da crueldade, do medo e da falta de amor, usando uma linguagem 
suave, a autora faz "sangrar" o coração do leitor, o qual vai fazer uma reflexão sobre temas diversos. No final da crônica mencionada, Machado tece um comentário que sintetiza toda a força expressiva de seu livro e que aponta para a realidade do nosso mundo contemporâneo, no qual ainda há homens com uma mentalidade patriarcal e utilitária: "Tenho medo dos homens que continuam a julgar as mulheres, os gays, os índios e outras minorias em nome de interesses próprios” (MACHADO, 2017, p. 56).

Em "Amor diluído", escrita numa linguagem poética e profunda, a autora fala da sociedade hedonista da qual ela faz parte, que tem como fundamento a noção de que, em todas as ações, o ser humano tem a intenção de obter mais prazer e menos sofrimento. Ela fala do amor, que ao longo do tempo está se diluindo no silêncio, na desesperança e na falta dos pequenos gestos de ternura.

A crônica "A morte paulatina da poesia", por meio de uma linguagem metafórica e realista, Machado expressa suas inquietações e a fragilidade humana. Usando o tempo psicológico, a autora faz referências a sua infância, de tempos felizes e sensações vividas. Porém, volta à realidade dos dias atuais e chama atenção do leitor para questões diversas, entre elas a enfermidade que se encontra a sociedade e suas políticas. A sociedade está perdendo a noção do essencial. Lucilene Machado usa um tom tênue e suave para falar de coisas sérias, palavras leves e ricas instigando o leitor a refletir sobre elas e a explorá-las.

Segundo Antônio Candido (2003), é importante insistir no papel da simplicidade, brevidade e graça próprias da crônica. Os professores tendem muitas vezes a incutir nos alunos uma ideia falsa de seriedade; uma noção duvidosa de que as coisas sérias são graves, pesadas, e que consequentemente a leveza é superficial. $\mathrm{Na}$ verdade, aprende-se muito quando se diverte, e aqueles traços constitutivos da crônica são um veículo privilegiado para mostrar de modo persuasivo muita coisa que, sendo divertida, atrai, inspira e faz amadurecer a nossa visão das coisas.

Os homens não amam as mulheres é um livro curto, de 112 páginas e a narrativa é tão leve e direta, que podemos considerá-lo como aquele livro que, conforme dizia Allan Poe (apud GOTLIB, 1990), deve-se ler em uma só assentada, para maior exaltação da alma, já 
que permite a contemplação e a reflexão sobre os sentimentos, à realidade e os problemas da contemporaneidade. O que mais chamará a atenção do leitor em relação ao livro mencionado é sua linguagem suave e cheia de humor lírico. É uma profunda reflexão sobre o ser humano, o amor e os sentimentos, e ainda sobre as manipulações, desilusões e principalmente sobre a ausência do amor, mas também sobre sua presença nos pequenos gestos.

Essa obra não deve ser apenas considerada como leitura composta por crônicas, ela deve ser vista também como um livro revelador e sedutor, mesmo em meio a tantas tribulações. Machado, por meio da escrita, busca responder as perturbações de seu espírito, ela nos faz ter um novo olhar sobre a vida moderna e suas transformações, o livro tem um caráter pessoal e intimista e, como sabemos, a linguagem pode afastar ou aproximar as pessoas e é este último sentido que prevalece na leitura da obra em apreço. A autora mostra um poder de comunicação e sensibilidade, fala dos laços sociais, da condição humana, busca, na escrita, descobrir sua própria identidade e sua própria humanidade questionando as contradições da sociedade.

O livro Os homens não amam as mulheres é, sem sombra de dúvida, uma contribuição relevante para a literatura Sul- Mato-Grossense e que, com toda certeza, agradará tanto aquele leitor que lê como um simples passatempo ou para o próprio deleite, quanto àquele que é mais crítico, e que pode pertencer ou não ao meio acadêmico.

\section{REFERÊNCIAS}

CANDIDO, Antonio. A vida ao rés-do-chão. In: Para gostar de ler. crônicas. São Paulo: Ática, 2003, p. 89-99, v. 5.

GOTLIB, Nádia Battela. A unidade de efeito. In: . Teoria do conto. Data da digitalização: 2004, p 18-21.

<http://www.avozdapoesia.com.br/autores.php?poeta_id=286 >Acesso em: 29 abr. 2017.

Recebido em: 20/03/2019. Aprovado em: 09/08/2019. 